\title{
The Tongue, The Gong and the Song: Olú Ọbáfẹmi at 70
}

Toyin Falola

The University of Texas at Austin

toyinfalola@austin.utexas.edu

Now that the bird of songs

dazzles us as it flies in the

sky, let us clap our hands and

pay homage to the carrier

of our country's light. In the

tribe of words, the calabash

of wisdom never misses.

From the streets of this land

to the world across, those who

know the music of hope know

the words weaved by you, Olú.

You are the song, you are the

gong. You are the dance that

lifts our feet to the drumbeats

of Àyángalú. Today we pay

homage to the Anígilájé

that entertains us with fecund

lyrics from the home of music.

İbà

We pay homage to the

seer who cast his spell

of light to map the future

of our land.

Bộmọdé ò bá bátàn, á bárọoọbá. 
Olúfẹmi, admired by the supreme deity; Ọbáfẹmi, adorned by the king; Níẹẹmi, loved in the purest way; Fẹmidénú, deeply admired by his friends. Who is that mortal that does not cherish such brilliance and treasure as Olúfẹmi Obáfẹmi? Having distinguished himself over the years as a remarkable, talented and ingenious playwright, poet, scholar and mentor, his praise of greatness chants itself. Many are gifted, true, but Ọ̀jọgbọ́n Ọbáfẹmi is truly gifted and in many ways too. At the crossroad to entering this world, some chose to be a seer, and some a maestro. Yet some others chose to be a troubadour or a reformer. Olú Obáfẹ́mi, however, understood there was no single pathway to the market, so he strode all the pathways to become the tongue, the gong, and the song.

A conscientious playwright, his artistry in works such Pestle on The Mortar, Nights of a Mystical Beast and The New Dawn, Scapegoats and Sacred Cows, New and Distant Cries to Running Dreams: Tales from Many Nations, reflects and refracts the post-colonial Nigerian predicaments and sociological matters. In Dark Times are Over?, for example, he satirized the decadence in Nigerian universities. The portrayal of happenings in Nigerian universities highlighted ills such as religious tension, prostitution, social injustice, and cultism. In Naira Has No Gender, he satirized the philosophy of possessive individualism of Nigerian politicians from a womanist point of view. This does not only border on gender and gendering, but also on the social formation of Nigeria with full recognition of the tension between tradition and modernity. While in Suicide Syndrome, he employs radical poetics to confront the socio-political organization and power relations of the Nigerian society thereby highlighting the deprivation and afflictions imposed on the masses. These three plays capture the man himself as an ènìyàn àtàtà who is concerned with our Nigerian situations.

From Ulli Beier, Herbert Ogunde to Moses Olaiya, Ògbóǹtarìgi Olú Obáfẹmi has done extensively well to properly position the significance of theatre in the socio-historical development of Nigeria while also advancing the frontiers of Theatre Criticism in Africa. More than just a renowned scholar, he is a man of service. There is no surprise that anywhere O'gá Olú served, as president of the Association of Nigerian Authors (ANA), president of the Nigerian Academy of Letters, director of Research at the National Institute of Policy and Strategic Studies and so on, he leaves a trail of accomplishments. After all, ẹni mọ ojú òuún ní pa obi n'írè. His service is not limited to just the scholarly arenas but to the generality of humanity. In 2018, when Prof. was conferred the Nigerian National Order of Merit (NNOM), the first Nigerian theatre critic to be ever awarded so, many of us believed that it is an award long overdue for a man of many merits. 
Whilst the nation was cowering at the chaos and tumult of the military regime, this illustrious son of Akutukpa Bunu and his gallant peers were busy counting the tiger's teeth. His repertoire of works includes 18 creative works, 14 single and co-authored books, and over a hundred scholarly articles published in local and international outlets. He truly stands out as an unforgettable legend. Who dares to ask, but a man who sings of hope and assures us hope persists, "Why should the society be organized in such a way that so many people can be suffering while a few have so much to waste?" Indeed, the phrase, "History will be kind to you," is derogatorily used these days. In the case of Ẹkùn Olú, it is a phrase that is already justified by his contributions to scholarship and humanity.

His ways are the gentle strides of a giant king that loves teaching many of us to submerge might and adopt sùúrù baba iwà (patience, the ultimate character). The efforts of olóye iwé are indeed gigantic and we can learn from the wisdom of such a great man. It is an honor for me to write this tribute to honor an àràbà. The gods have smiled on him. It is a blessing to live long and be celebrated.

İwó is the home of Odídẹrẹ. Obáfẹmi, the scion of the land, the veil of your kindness spreads across the world. You--the skilful hunter who kills the bloated dreams of power-drunken leaders. You-the flute that produces tunes that gather our ears. Since today is the birthday of the wordsmith whose name cuddles our tongues, may your sea of songs never dry. Every year, kolanut visits the market of the world. Every year, bitter kola graces the market of the world. Bàbá, may your feet never slip on the eye of the earth. May you grow old to witness many seasons of festiveness.

Koko lara ota a le. I wish you the brightness of the moon, the colorfulness of the rainbow, the endless flow of the 
sea.

Àṣèí sàmọdún. 